\title{
Results on Parasitic Level of Larvae and Pupae of Cameraria ohridella Deschka-Dimić
}

\author{
Ion OLTEAN ${ }^{1}$, Cristina SOPORAN ${ }^{1}$, Vasile FLORIAN ${ }^{1}$, Mircea VARGA ${ }^{1}$, Laura MACAVEI ${ }^{1}$, Teodora \\ FLORIAN $^{1 *}$
}

${ }^{1}$ Department Environment and Plant Protection. University of Agricultural Sciences and Veterinary Medicine Faculty of Agriculture

* corresponding author: florian.teodora@yahoo.com

Bulletin USAMV series Agriculture 72(1)/2015

Print ISSN 1843-5246; Electronic ISSN 1843-5386

DOI 10.15835/buasvmcn-agr: 11156

\begin{abstract}
The main pest of ornamental chestnut of landscaping in Cluj-Napoca is Cameraria ohridella Deschka-Dimić. Frequency of attacked leaves shows fluctuation from one year to another and from one location to another. Upon the numerical density of the population of this pest, an important role is repesented by useful entomofauna, especially species of parasitoids. During the period 2012-2013 was studied the percentage of parasitic larvae and pupae of Cameraria ohridella Deschka-Dimić in two locations. In 2012 the parasitic level (\%) of larvae in the central park of the city was on average $7.9 \%$ and $5.7 \%$ on the Paris Street, leading on 2013 at rate of parasitic level (\%) in central park to $9.8 \%$ and $6.3 \%$ on the Paris Street. Parasitic level (\%) of pupae in 2012 was 8.8\% in Central Park and 6.1\% on the Paris Street, and in 2013 the parasitic level (\%) was 10.4\% in Central Park and 6 9\% on the Paris Street. Parasitic level (\%) of larvae and pupae of Cameraria ohridella species is different from one location to another. This is due to the fact that entomofauna parasitoid is polyphagous, and where we have a more diversified composition of tree species, the chances of developing parasitoid hymenoptera are higher.
\end{abstract}

Keywords: Cameraria ohridella Deschka-Dimić, parasitic larvae, pupae parasitic.

\section{INTRODUCTION}

Mining moth has become a dangerous pest and creates major problems for the protection of ornamental chestnut (Aesculus spp) for almost all European countries. (Péré et al., 2010). In our country during the last 15 years has spread with great rapidity and raises protection problems of ornamental chestnut, especially in green spaces of urban centers. The numerical density of population regulation involve a series of natural parasites, which were identified both abroad and in our country (Stolz, 1997; Moreth et al., 2000; Balázs et al., 2002; Grabenweger, 2002; Lethmayer, 2002, Freise et al., 2002; Stojanovic and Markovic, 2004; Ferracini and Alma, 2007). Following studies carried out by the discipline of Entomology at UASVM Cluj-
Napoca in 2000-2006, it was found that larvae and pupae of themining moth may be affected by zoophagus entomofauna, especially by parasitoid hymenoptera. At investigated area parasitic level (\%) ranged from 3 to $11 \%$ (PERJU et al. 2004, 2007; OLTEAN et al., 2006). PERJU et al. 2007, identified 16 species of Hymenoptera parasitoid in Cluj area. From the family Pteromalide was identified: Pteromalus semotus Walk. Most of them belong to the family Eulophidae: Minotetrastichus frontalis Ness., Pnigalio agraules Walk., Pnigalio pectinicornis L., Closterocerus trifasciatus Westw., Sympiesis sericeicornis Ness., Pediobius saulius Walk., Minotetrastichus platanellus Merc., Baryscapus nigroviolaceus Ness., Chrysocharis sp., Closterocerus lyonetiae Ferr., Pediobius sp., Pnigalio 
soemius Walk., Pnigalio sp. Was reported also a specie of the family Encirtidae, but unidentified.

\section{AIMS}

Studying the parasitic level of larvae and pupae of Cameraria ohridella Deschka-Dimić in Cluj, during 2012-2013.

\section{MATERIALS AND METHODS}

At the period 2012-2013, we proceeded to determine the parasitic level of larvae and pupae of Cameraria ohridella Deschka-Dimić in two locations. A first location was central park (location with a wide variety of trees from different species), and the second location were chestnut trees existing on Paris Street (location where we can find a few specimens from other tree species). During the months from May to September were randomly collected 50 attacked leaves. The leaves were analyzed in the lab, noting the total number of larvae and pupae in each sample, identifying larvae or pupae parasitized, without identifying parasitoid.

\section{RESULTS}

Table 1 present the results from 2012 regarding leaves collected in central park. The total number of larvae present in one sample ranged from 69 to 283 larvae. The average number of larvae reportedin one leaf was approximately 3.5 larvae / leaf. It should be noted that the number of mines on a leaf was much higher, which increases from one generation to another, but when the observation was conducted the mines were empty, being abandoned by the previous generation of adults.

Regarding the number of parasitized larvae in a sample, it has fluctuated between 5 and 24 larvae. Percentage of parasited larvae ranged from 4.7\% (September 10) and 12.9\% (August 29). The highest level of parasited larvae is reported in the second generation, followed by the last generation larvae. Throughout the vegetation period, the average was $7.9 \%$ parasited larvae.

Pupae were reported from June 24, and the number of pupae in a sample analyzed ranged from 83 to 312 pupae. The average number of pupae present in a leaf was about 3.2 pupae / leaf.

Of the 1451 pupae examined, 127 were parasitized, with an average of the parasited level $8.8 \%$ (0.9 percentage points more than the percentage of parasited larvae). During the period of observatin, the percentage of parasited pupae ranged from 3.6\% (first observation) and $16.2 \%$ (August 29). As in case of larvae the level of parasited pupae is much higher in the second period of life cycle, especially in the last generation of pupae.

Tab. 1. The attack level of Cameraria ohridella Deschka-Dimić larvae and chrysalis (Cluj-Napoca, Central Park, 2012)

\begin{tabular}{cccccccc}
\hline No. & $\begin{array}{c}\text { Observation } \\
\text { date }\end{array}$ & $\begin{array}{c}\text { Total } \\
\text { no. }\end{array}$ & Parasited larvae & $\begin{array}{c}\text { Analysed larvae } \\
\text { of parasitic } \\
\text { larvae }\end{array}$ & $\begin{array}{c}\text { Total no. } \\
\text { Parasited } \\
\text { pupae }\end{array}$ & $\begin{array}{c}\text { \% of parasitic } \\
\text { pupae }\end{array}$ \\
\hline 1 & 25.05. & 79 & 6 & 7,6 & - & - & - \\
\hline 2 & 5.06. & 158 & 13 & 8,2 & - & - & - \\
\hline 3 & 15.06 & 197 & 12 & 6,1 & - & - & 3,6 \\
\hline 4 & 24.06 & 217 & 9 & 4,2 & 83 & 3 & 7,8 \\
\hline 5 & 3.07 & 283 & 18 & 6,4 & 102 & 8 & 4,9 \\
\hline 6 & 15.07 & 171 & 14 & 8,2 & 123 & 6 & 9,3 \\
\hline 7 & 28.07 & 192 & 21 & 10,9 & 97 & 9 & 14 \\
\hline 8 & 9.08 & 269 & 19 & 7,1 & 173 & 37 & 14,7 \\
\hline 9 & 18.08 & 208 & 24 & 11,3 & 252 & 37 & 16,2 \\
\hline 10 & 29.08 & 132 & 17 & 12,9 & 142 & 23 & 11,2 \\
\hline 11 & 10.09 & 107 & 5 & 4,7 & 167 & 19 & 2,6 \\
\hline 12 & 25.09 & 69 & 7 & 10,1 & 312 & 8 & 8,8 \\
\hline
\end{tabular}


Table 2 gives an overview of the situation on leaves colected from Paris Street. In this location, from the same number of leaves analyzed were reported 2201 larvae, noting an average of 3.7 larvae / leaf ( 0.2 mines more than the previous location). Of larvae analyzed, 125 were parasitized, with an average level of pasited larvae of $5.7 \%$. In this location the percentage of parasited larvae varied between $3.1 \%$ and $8.9 \%$.

If we compare the percentage of parasited larvae of the two locations, we see that in Central Park this parameter was higher by 2.2 percentage points. This is due, of course, to the fact that parasitoid entomofauna is polyphagous, and in Central Park where we have a diverse composition of tree species, the chances of developing parasitoid hymenoptera are higher.

Since the last days of June, on the leaves collected were reported the first pupae. On the leaves collected from that date until the end of the experiment, the average number of pupae / leaf was 2.9 (0.3 pupae less than in Central Park). The average percentage of parasited pupae analyzed was $6.1 \%$ (2.7 percentage points less than in Central Park). This parameter varied between 3.5\% (first observation) and 8.9\% (in observation of August 29).

Table 3 presents the results of observations from 2013 on leaves collected from the city's central park. The total number of larvae present in a sample varied between 57 and 318. Average number of larvae observed in a leaf was about 4.3 larvae / leaf, 0.8 more larvae, compared to previous year.

Of the 2787 larvae analyzed, the number of parasitized larvae was 274, with an average of parasitic level for entire period of $9.8 \%$. Compared to the previous year is observed an increase in the percentage of parasitic level by 1.9. This is probably due to two factors: the higher level of parasitized population species and climatic conditions more favorable this year for the development of parasitoid hymenoptera entomofauna (this year there was an atmospheric humidity much higher than the previous year). The number of parasited larvae in a sample varied between 5 and 44 larvae. Percentage of parasited larvae varied between $6.1 \%$ and $15.4 \%$. Comparing to the previous minimum level of parasited larva increased by 1.4 percentage points, and the maximum parasitic level increased by 2.5 percentage points. The highest level of parasited larvae is reported in the second generation, followed by the last generation larvae.

Pupae were reported from June 20, and the number of pupae in a sample analyzed varied between 36 and 291. The average number of pupae present in a leaf was about 3.4 pupae / leaf (0.2 pupae more than the previous year).

Tab. 2. The attack level of Cameraria ohridella Deschka-Dimić larvae and chrysalis (Cluj-Napoca, Paris street, 2012)

\begin{tabular}{cccccccc}
\hline & & & \multicolumn{2}{c}{ Analysed larvae } & & Analysed chrysalis \\
\cline { 3 - 8 } No. & $\begin{array}{c}\text { Observation } \\
\text { date }\end{array}$ & $\begin{array}{c}\text { Total } \\
\text { no. }\end{array}$ & Parasited larvae & $\begin{array}{c}\text { \% of parasitic } \\
\text { larvae }\end{array}$ & Total no. & $\begin{array}{c}\text { Parasited } \\
\text { pupae }\end{array}$ & $\begin{array}{c}\text { \% of parasitic } \\
\text { pupae }\end{array}$ \\
\hline 1 & 25.05. & 48 & 2 & 4,2 & - & - & - \\
\hline 2 & 5.06. & 135 & 7 & 5,2 & - & - & - \\
\hline 3 & 15.06 & 172 & 9 & 5,2 & - & - & 3,5 \\
\hline 4 & 24.06 & 256 & 12 & 4,7 & 57 & 2 & 4,4 \\
\hline 5 & 3.07 & 249 & 13 & 5,2 & 114 & 5 & 2,9 \\
\hline 6 & 15.07 & 277 & 11 & 4,0 & 137 & 4 & 4,8 \\
\hline 7 & 28.07 & 202 & 18 & 8,9 & 125 & 6 & 7,4 \\
\hline 8 & 9.08 & 273 & 13 & 4,8 & 279 & 15 & 8,4 \\
\hline 9 & 18.08 & 237 & 21 & 8,9 & 142 & 11 & 8,5 \\
\hline 10 & 29.08 & 143 & 12 & 8,4 & 101 & 9 & 7,3 \\
\hline 11 & 10.09 & 127 & 4 & 3,1 & 129 & 11 & 6,1 \\
\hline 12 & 25.09 & 82 & 3 & 3,7 & 217 & 16 & 79 \\
\hline
\end{tabular}


Of the 1704 pupae examined, 177 were parasited, with annual average percentage of $10.4 \%$ (0.6 percentage points more than the percentage of parasitic larvae). Compared to the previous year was reported an increase in the level of parasited pupae by 1.6 percentage points.
Over the period of development of the pupal stage, the percentage of parasitic pupae ranged from $7.4 \%$ (first observation) and 14\% (August 8). This year the percentage of parasitic pupae is much higher in the second period of biological cycle, especially in pupae of the second generation.

Tab.3. The attack level of Cameraria ohridella Deschka-Dimić larvae and chrysalis (Cluj-Napoca, Central Park, 2013)

\begin{tabular}{cccccccc}
\hline No. $\begin{array}{c}\text { Observation } \\
\text { date }\end{array}$ & $\begin{array}{c}\text { Total } \\
\text { no. }\end{array}$ & Parasited larvae & $\begin{array}{c}\text { A of parasitic } \\
\text { larvae }\end{array}$ & Total no. & $\begin{array}{c}\text { Parasited chrysalis } \\
\text { pupae }\end{array}$ & $\begin{array}{c}\text { \% of parasitic } \\
\text { pupae }\end{array}$ \\
\hline 1 & 22.05. & 58 & 5 & 8,6 & - & - & - \\
\hline 2 & 30.05 & 116 & 9 & 7,8 & - & - & - \\
\hline 3 & 9.06 & 212 & 13 & 6,1 & - & - & - \\
\hline 4 & 20.06 & 279 & 17 & 6,1 & 36 & - & - \\
\hline 5 & 29.06 & 306 & 33 & 10,8 & 121 & 9 & 7,4 \\
\hline 6 & 10.07 & 257 & 19 & 7,4 & 145 & 16 & 11,1 \\
\hline 7 & 18.07 & 281 & 27 & 9,6 & 174 & 19 & 10,9 \\
\hline 8 & 29.07 & 278 & 31 & 11,2 & 203 & 27 & 13,3 \\
\hline 9 & 8.08 & 318 & 44 & 13,8 & 229 & 32 & 14,0 \\
\hline 10 & 19.08 & 246 & 38 & 15,4 & 185 & 21 & 11,4 \\
\hline 11 & 28.08 & 197 & 13 & 6,6 & 217 & 17 & 7,8 \\
\hline 12 & 8.09 & 182 & 19 & 10,4 & 103 & 11 & 10,7 \\
\hline 13 & 19.09 & 57 & 6 & 10,5 & 291 & 25 & 8,6 \\
\hline & TOTAL & 2787 & 274 & 9,8 & 1704 & 177 & 10,4 \\
\hline
\end{tabular}

Tab.4. The attack level of Cameraria ohridella Deschka-Dimić larvae and chrysalis (Cluj-Napoca, Paris street, 2013)

\begin{tabular}{cccccccc}
\hline No. & $\begin{array}{c}\text { Observation } \\
\text { date }\end{array}$ & $\begin{array}{c}\text { Total } \\
\text { no. }\end{array}$ & $\begin{array}{c}\text { Parasited } \\
\text { larvae }\end{array}$ & $\begin{array}{c}\text { \% of parasitic } \\
\text { larvae }\end{array}$ & $\begin{array}{c}\text { Total } \\
\text { no. }\end{array}$ & $\begin{array}{c}\text { Parasited } \\
\text { pupae }\end{array}$ & $\begin{array}{c}\text { \% of parasitic } \\
\text { pupae }\end{array}$ \\
\hline 1 & 22.05. & 43 & 2 & 4,7 & - & - & - \\
\hline 2 & 30.05 & 97 & 4 & 4,1 & - & - & - \\
\hline 3 & 9.06 & 143 & 7 & 4,9 & - & - & - \\
\hline 4 & 20.06 & 189 & 11 & 5,8 & 72 & 3 & 4,2 \\
\hline 5 & 29.06 & 217 & 12 & 5,5 & 98 & 5 & 5,1 \\
\hline 6 & 10.07 & 239 & 14 & 5,6 & 116 & 9 & 7,8 \\
\hline 7 & 18.07 & 212 & 16 & 7,5 & 131 & 11 & 8,4 \\
\hline 8 & 29.07 & 261 & 19 & 7,3 & 285 & 15 & 5,3 \\
\hline 9 & 8.08 & 209 & 13 & 6,2 & 156 & 14 & 9,0 \\
\hline 10 & 19.08 & 230 & 21 & 9,1 & 103 & 9 & 8,7 \\
\hline 11 & 28.08 & 148 & 9 & 6,1 & 114 & 8 & 7,0 \\
\hline 12 & 8.09 & 109 & 7 & 6,4 & 153 & 13 & 8,5 \\
\hline 13 & 19.09 & 29 & 1 & 3,4 & 277 & 17 & 6,2 \\
\hline & TOTAL & 2126 & 135 & 6,3 & 1505 & 104 & 6,9 \\
\hline
\end{tabular}


Table 4 gives an overview of the percentage of parasited larvae and pupae observed on leaves collected on Paris Street. On the leaves collected from this location were reported in 2126 larvae, with an average of 3.3 larvae / leaf. The total number of larvae / sample varied between 29 and 239 larvae larvae. Of larvae analyzed, 135 were parasited larvae, with an average of $6.3 \%$. In this location the percentage of parasitic larvae varied between $3.4 \%$ and $9.1 \%$. In this location, compared to previous year was reported an increase in the proportion of parasited larvae by 0.6 percentage points.

If we compare the percentage of parasited larvae in the two locations this year, we see that in Central Park this parameter was 3.5 percentage points higher reported situation in the previous year. This confirms the hypothesis stated above, meaning that the parasitoid entomofauna it is polyphagous and in Central Park where we have a diverse composition of tree species, the chances of developing parasitoid hymenoptera are higher.

In the last decade of June, in the leaves collected were reported the first pupae. On the leaves collected from that date until the end of the experiment, the average number of pupae / leaf was 3 (0.4 less pupae than in Central Park). The average percentage of parasited pupae analyzed was $6.9 \%$ (3.5 percentage points less than in Central Park). Compared to the previous year, the proportion of parasited pupae increase by 0.8 percentage points. This parameter ranged from 34.2\% (first observation) and 9\% (August 8).

\section{CONCLUSION}

1. On the chestnut trees in the central park of the city, the percentage of parasited larvae in 2012 was on average $7.9 \%$, and in 2013 was on average $9.8 \%$. Percentage of parasited pupae in 2012 was $8.8 \%$, while in 2013 the proportion of parasited pupae was $10.4 \%$.

2. On the chestnut trees located on Paris Street, the percentage of parasited larvae in 2012 was on average $5.7 \%$, and in 2013 was on average $6.3 \%$. Percentage of parasited pupae in 2012 was $6.1 \%$, while in 2013 the proportion of parasited pupae was $6.9 \%$.

3. Percentage of parasited larvae and pupae of Cameraria ohridella Deschka-Dimić species is different from one location to another. This is due to the fact that parasitoid entomofauna is polyphagous, and where we have a diverse composition of tree species, the chances of developing parasitoid hymenoptera are higher.

4. Percentage of parasitic increased in 2013 in both locations monitored. In the Central Park was reported the highest percentage of parasited larvae and pupae of Cameraria ohridella DeschkaDimić. In the two years the activity of parasitoids is more intense on pupal stage, in both locations.

5. The highest level of parasited larvae is reported in the second generation, followed by the last larva generation. Percentage of parasited pupae is much higher in the second period of biological cycle, especially in the last generation of pupae.

\section{REFERENCES}

6. Balázs K, Thuróczy CS, Ripka G (2002). Parasitoids of horse chestnut leaf miner Cameraria ohridella Deschka et Dimic, (Lepidoptera: Gracillariidae) in Hungary, In: Melika G., Thuróczy C. S., (ed). Proceedings of the International Symposium on Parasitic Hymenoptera: Taxonomy and Biological Control, Kőszeg, Hungary:405-412.

7. Ferracini C, Alma A (2007). Evaluation of the community of native eulophid parasitoids on Cameraria ohridella Deschka and Dimic in urban areas. Environmental Entomology 36(5): 1147-1153.

8. Freise JF, Hietland W, Tosevski I (2002). Parasitism of the horsechestnut leafminer Cameraria ohridella (DeschkaDimić) (Lep., Gracillariidae) in Serbia and Macedonia. J. Pest. Sci., 75: 6.

9. Grabenweger G (2002). Primary and secondary parasitism in then Cameraria ohridella complex (Lepidoptera: Gracillariidae) In: Melika G, Thuroczy Cs (ed) Proceedings of the International Symposium on Parasitic Hymenoptera: Taxonomy and Biological Control, Kőszeg, Hungary, pag:396-399.

10. Lethmayer C (2002). The parasitism of horse chestnut leafmining moth (Cameraria ohridella) in Austria. In: Melika G, Thuroczy Cs (ed). Proceedings of the International Symposium on Parasitic Hymenoptera: Taxonomy and Biological Control, Kőszeg, Hungary : 400404.

11. Moreth L, Baur H, Schőnitzer K, Diller E (2000). Yum Parasitoidenkomplex der Rosskastanien-miniermotte in Bayern (Cameraria ohridella, Gracilariidae, Lithococolletinae), Mitt. Dtsch. Ges. alg. angew. Entomol.12:489-492.

12. Oltean I, Perju T, Ghizdavu I, Bunescu H, Bodiş I, Gânscă L, Oprean I, Ciotlăuș I, Maxim S (2006). Molia minieră a castanului, Cameraria ohridella Deschka-Dimić.Editura AcademicPres Cluj-Napoca:115.

13. Pere C, Augustin S, Turlings TCV, Kenis M (2010). The invasive alien leaf miner Cameraria ohridella and the native tree Acer pseudoplatanus: a fatal attraction? Agricultural and Forest Entomology 12(2):151-159. 
14. Perju T, Oltean I, Oprean I, Ecobici M (2004). The pests of horse chestnut thee - Aesculus hippocastanum L. in Romania. Journal Central European Agriculture, Croația 5(4):331-336.

15. Perju T, Andriescu I, Ureche C, Oltean I, Trifan A, Timuş A (2007). Complexul de parazitoizi ai moliei miniere Cameraria ahridella Deschka-Dimic, dăunătoare castanului ornamental Aesculus hippocastanum în România, Chişinău. Lucrări ştiințifice 15(3):233-237.
16. Stojanovic A, Markovic C (2004). Parasitoid complex of Cameraria ohridella (Lepidoptera: Gracillariidae) in Serbia. Phytoparasitica 32:132-140.

17. Stolz M (1997). Untersuchungen über larval-und puppenparasitoide von Cameraria ohridella in Hinleck auf ihre Eignung zur Laborzucht. Forstschutz Aktuell 211:36-41. 